\title{
Synthesis and biological evaluation of new salvinorin A analogues incorporating natural amino acids
}

\author{
Jakub Fichna ${ }^{a, b}$, Kevin Lewellyn ${ }^{a}$, Feng Yan ${ }^{c}$, Bryan L. Roth ${ }^{c}$, and Jordan K. Zjawionya \\ aDepartment of Pharmacognosy and Research Institute of Pharmaceutical Sciences, School of \\ Pharmacy, University of Mississippi, University, MS, USA bepartment of Biomolecular \\ Chemistry, Medical University of Lodz, Lodz, Poland 'Department of Pharmacology, University of \\ North Carolina Medical School, Chapel Hill, NC, USA
}

\begin{abstract}
The synthesis and in vitro evaluation of a new series of salvinorin $A$ analogues substituted at the $\mathrm{C}(2)$ position with natural amino acids is reported. Compound 12, containing Val, displayed high affinity and full agonist activity at the kappa-opioid receptor. Analogues with bulky and/or aromatic residues were inactive, showing the importance of size and electronegativity of $\mathrm{C}(2)$ substituents for binding affinity of salvinorin A derivatives.
\end{abstract}

\section{Keywords}

Salvia divinorum; salvinorin B; neoclerodane diterpenoid; natural amino acids; opioid receptor ligands

A neoclerodane diterpenoid salvinorin A (SA) (1), the active ingredient of the Mexican plant Salvia divinorum, is a selective kappa-opioid receptor (KOR) agonist with potent in vivo activity (Fig. 1). ${ }^{1}$ Recent reports point out a potential role in the treatment of functional gastrointestinal (GI) disorders, which is in accord with the traditional use of S. divinorum extracts. SA potently inhibits smooth muscle contractility and motility in vivo in the upper and lower GI, as well as influences the epithelial ion transport in a KOR-dependent manner under both physiological and pathophysiological conditions. ${ }^{2}$ Pharmacokinetic studies in animals and in humans indicate that SA is rapidly degraded and that its in vivo effects are short-lasting, regardless of route of administration. ${ }^{3}$ Therefore numerous attempts have been made to synthesize SA derivatives with potent affinity at KOR and prolonged in vivo actions. ${ }^{2}$ The structure-activity relationship (SAR) studies of SA have demonstrated that the size and electronegativity of the substituent at the $\mathrm{C}(2)$ position is critical for activity at opioid receptors. It was shown that SA derivatives with spatially restrained (3-4 carbon atoms) lipophilic groups at $\mathrm{C}(2)$ display highest binding affinity and potency at KOR.4 ${ }^{-9}$ However, incorporation of non-lipophilic substituents, such as amines and amino acids also

(C) 2010 Elsevier Ltd. All rights reserved.

Corresponding author: Prof. Jordan K. Zjawiony, PhD, Department of Pharmacognosy and Research Institute of Pharmaceutical Sciences, School of Pharmacy, University of Mississippi, PO Box 1848, University, MS 38677-1848, USA, Tel +662 915 7290, Fax +6629156975 jordan@olemiss.edu.

Publisher's Disclaimer: This is a PDF file of an unedited manuscript that has been accepted for publication. As a service to our customers we are providing this early version of the manuscript. The manuscript will undergo copyediting, typesetting, and review of the resulting proof before it is published in its final citable form. Please note that during the production process errors may be discovered which could affect the content, and all legal disclaimers that apply to the journal pertain. 
resulted in potent and selective KOR ligands.6;8 Interestingly, bulkier substituents tend to reduce KOR affinity and in some cases increase mu-opioid receptor (MOR) affinity. ${ }^{2}$

In an attempt to further investigate the role of $\mathrm{C}(2)$ in SA binding at KOR we synthesized a series of derivatives substituted in this position with natural non-aromatic and aromatic amino acids and evaluated their in vitro affinities and potencies. Previous studies showed that the introduction of an aromatic moiety in position 2 increased affinity at MOR. ${ }^{10}$ Therefore, N-(9-fluorenylmethoxycarbonyl) (Fmoc)-protected derivatives were also synthesized and their affinities compared with those of respective non-protected analogues.

SA (1) was isolated from the leaves of $S$. divinorum and purified as previously described. ${ }^{11}$ Compound $\mathbf{1}$ was converted to salvinorin B (2), which served as the starting material for the preparation of the $\mathrm{C}(2)$-modified analogs 3-14 (Table 1). Compounds 3-8 were synthesized from N-Fmoc-protected amino acids using $\mathrm{N}$-methylmorpholine as a catalyst and TBTU as a coupling reagent (Scheme 1). ${ }^{12}$ Analogs $\mathbf{9 - 1 4}$ were obtained from respective N-Fmocprotected derivatives by deprotection with piperidine. ${ }^{13 ; 14}$

Spectral data $\left({ }^{1} \mathrm{H}\right.$ NMR, ${ }^{13} \mathrm{C}$ NMR, high-resolution mass) consistent with the proposed structures were obtained for all the compounds prepared in this study.

The KOR radioligand binding assays were conducted according to previously described procedures and the results are presented in Tables 2 and $3 .^{15}$

$\left.{ }^{35} \mathrm{~S}\right] \mathrm{GTP} \gamma \mathrm{S}$ binding assays at MOR, DOR and KOR were performed for analogue $\mathbf{1 2}$ and $\mathrm{SA}$, which was used as a reference compound. The in vitro pharmacological data for SA and $\mathbf{1 2}$ are listed in Table 4.

Preliminary in vitro binding data in opioid receptor-expressing cells showed that the introduction of N-Fmoc-protected amino acids at the $\mathrm{C}(2)$ position of SA resulted in loss of affinity at KOR, depending on the amino acid incorporated and the radiolabelled ligand used (Table 2). Only in the case of the Val-substituted analogue (12) did the removal of the Fmoc protecting group significantly increase its ability to displace selective ligands at KOR binding sites, making it almost equipotent with the parent compound, SA. Interestingly, the Ala-derivative (10) displayed good affinity at KOR against $\left[{ }^{3} \mathrm{H}\right] \mathrm{U} 69,593$, but did not displace KOR antagonist binding, as assessed with $\left[{ }^{3} \mathrm{H}\right]$ diprenorphine. Concentrationresponse curves showed that analogue $\mathbf{1 2}$ had high affinity and selectivity at KOR $\left(\mathrm{K}_{\mathrm{i}}\right.$ values of $42.0 \pm 2.05$ and $0.75 \pm 0.62 \mathrm{nM}$ for $\mathbf{1 2}$ and SA, respectively; Table 3), while the affinity of $\mathbf{1 0}$ was in a $\mu \mathrm{M}$ range (Table 3 ). To determine the agonist activity of $\mathbf{1 2}$ at KOR, $\left.{ }^{[35} \mathrm{S}\right] \mathrm{GTP} \gamma \mathrm{S}$ binding assays were performed. The potency of Val-substituted derivative (12) was lower than that of the parent compound (see Table 4); however, the novel analogue was a full agonist at KOR (Table 4).

Amino acid analogues of SA substituted at the $\mathrm{C}(2)$ position were reported earlier, but only N-Boc-Gly-derivative displayed good affinity at KOR $(90 \pm 10 \mathrm{nM}) .8$ The introduction of $\mathrm{N}$-Ac-Gly, N,N-diMeGly and N,N-diMeGly gave inactive compounds, while the Gly and Sar analogues were unstable.6 In our study the modification with Val resulted in a potent and selective KOR agonist, with affinity in the $\mathrm{nM}$ range. These data suggest that the $\mathrm{C}(2)$ position in the structure of SA is important for its interaction with the opioid receptors and that only small, non-aromatic amino acids fit into the binding pocket of KOR.

This is in good agreement with a recently published paper by McGovern et al. on molecular modelling of $\mathrm{C}(2)$-analogues of SA. ${ }^{16} \mathrm{~A}$ region of bulk tolerance, falling within a receptor hydrophobic pocket, was observed around the $\mathrm{C}(2)$ position, extending approximately three carbon atoms in length from the carbonyl carbon. It has also been shown that the methyl and 
carbonyl groups, as well as a hydrophobic moiety at a terminal position of the $\mathrm{C}(2)$ substituent are important for optimal ligand affinity. Interestingly, the structure of Valderivative, which seems to be well-tolerated by the putative binding pocket, accommodates all above mentioned criteria.

Unexpectedly, in the study of Beguin et al. ${ }^{6}$ and in our assays, the Ala-derivative did not displace $\left[{ }^{3} \mathrm{H}\right]$ diprenorphine from its binding at KOR. However, here we observed that the Ala-substituted analogue displayed $\mu \mathrm{M}$ affinity against $\left[{ }^{3} \mathrm{H}\right] \mathrm{U} 69,593$, clearly demonstrating that the choice of the radiolabeled compound can influence the reported binding affinity data.

In conclusion, we were able to obtain a series of novel amino acid analogues of SA, of which the Val-derivative displayed highest affinity at KOR, comparable to that of the parent compound. Due to relative ease of our approach and the availability of reagents the synthetic strategy used in this study may result in a vast library of analogues and could become the method of choice in preparation of novel derivatives based on SA structure.

\section{Acknowledgments}

This work was supported by the NIH Grant R01 DA017204 and the NIMH Psychoactive Drug Screening Program. The authors wish to thank Lukasz Kutrzeba for his help in extraction of salvinorin A from plant material.

\section{References and notes}

1. Roth BL, Baner K, Westkaemper R, Siebert D, Rice KC, Steinberg S, Ernsberger P, Rothman RB. Proc.Natl.Acad.Sci.U.S.A 2002;99:11934. [PubMed: 12192085]

2. Fichna J, Schicho R, Janecka A, Zjawiony JK, Storr M. Drug News Perspect 2009;22:383. [PubMed: 19890495]

3. Wang Y, Chen Y, Xu W, Lee DY, Ma Z, Rawls SM, Cowan A, Liu-Chen LY. J Pharmacol.Exp.Ther 2008;324:1073. [PubMed: 18089845]

4. Lee DY, Karnati VV, He M, Liu-Chen LY, Kondaveti L, Ma Z, Wang Y, Chen Y, Beguin C, Carlezon WA Jr. Cohen B. Bioorg.Med.Chem.Lett 2005;15:3744. [PubMed: 15993589]

5. Munro TA, Duncan KK, Xu W, Wang Y, Liu-Chen LY, Carlezon WA Jr. Cohen BM, Beguin C. Bioorg.Med.Chem 2008;16:1279. [PubMed: 17981041]

6. Beguin C, Richards MR, Wang Y, Chen Y, Liu-Chen LY, Ma Z, Lee DY, Carlezon WA Jr. Cohen BM. Bioorg.Med.Chem.Lett 2005;15:2761. [PubMed: 15869877]

7. Beguin C, Richards MR, Li JG, Wang Y, Xu W, Liu-Chen LY, Carlezon WA Jr. Cohen BM. Bioorg.Med.Chem.Lett 2006;16:4679. [PubMed: 16777411]

8. Tidgewell K, Harding WW, Lozama A, Cobb H, Shah K, Kannan P, Dersch CM, Parrish D, Deschamps JR, Rothman RB, Prisinzano TE. J Nat.Prod 2006;69:914. [PubMed: 16792410]

9. Stewart DJ, Fahmy H, Roth BL, Yan F, Zjawiony JK. Arzneimittelforschung 2006;56:269. [PubMed: 16724512]

10. Harding WW, Tidgewell K, Byrd N, Cobb H, Dersch CM, Butelman ER, Rothman RB, Prisinzano TE. J Med.Chem 2005;48:4765. [PubMed: 16033256]

11. Kutrzeba LM, Karamyan VT, Speth RC, Williamson JS, Zjawiony JK. A.Pharm.Biol 2009;47:1078.

12. General procedure for synthesis of N-Fmoc-amino acid analogues of salvinorin A (3-8): To a stirred solution of 2 ( $20 \mathrm{mg}, 0.05 \mathrm{mmol}, 1$ equiv) in $\mathrm{CH}_{2} \mathrm{Cl}_{2}(2 \mathrm{ml})$, the $\mathrm{N}$-Fmoc-amino acid (3 equiv), and $\mathrm{N}$-methylmorpholine ( 3 equiv) was added TBTU ( 3 equiv). The solution was stirred at $50^{\circ} \mathrm{C}(24 \mathrm{~h})$, concentrated under reduced pressure and purified by column chromatography $\left(\mathrm{SiO}_{2}\right.$; 2:1, hexane:EtOAc) to obtain the desired product.

13. General procedure for deprotection of N-Fmoc-amino acid analogues of salvinorin A (9-14): respective $\mathrm{N}$-Fmoc-amino acid derivative of salvinorin A (1 equiv) was dissolved in $\mathrm{CH}_{2} \mathrm{Cl}_{2}$ and piperidine ( $3 \mathrm{eq})$ was added. The solution was stirred at RT $(1.5 \mathrm{~h})$, concentrated under reduced 
pressure and purified by column chromatography $\left(\mathrm{SiO}_{2} ; 2: 1\right.$, hexane:EtOAc) to obtain the desired product.

14. Synthesis of 2-(2'-(S)-amino-3-methylbutanoate) salvinorin B (12): yield 76.9\% starting from 2 , a white solid, $\delta 0.62$ (1:1, hexane:EtOAc); ${ }^{1} \mathrm{H}$ NMR $\left(400 \mathrm{MHz}, \mathrm{CDCl}_{3}\right) \delta 1.02-1.04(\mathrm{~d}, J=6.8 \mathrm{~Hz}$, $3 \mathrm{H}), 1.07-1.10(\mathrm{~d}, J=6.8 \mathrm{~Hz}, 3 \mathrm{~Hz}), 1.14(\mathrm{~s}, 3 \mathrm{H}), 1.47(\mathrm{~s}, 3 \mathrm{H}), 1.57-1.75(\mathrm{~m}, 4 \mathrm{H}), 1.77-1.84(\mathrm{~m}$, $1 \mathrm{H}), 2.07-2.11(\mathrm{dd}, J=10.8,1.6 \mathrm{~Hz}, 1 \mathrm{H}), 2.16-2.21(\mathrm{~m}, 2 \mathrm{H}), 2.30-2.36(\mathrm{~m}, 2 \mathrm{H}), 2.48-2.55(\mathrm{dd}, J=$ $13.4,5.2 \mathrm{~Hz}, 1 \mathrm{H}), 2.75-2.80(\mathrm{dd}, J=13.0,3.5 \mathrm{~Hz}, 1 \mathrm{H}), 3.44-3.46(\mathrm{~d}, J=4.4 \mathrm{~Hz} 1 \mathrm{H}), 3.75(\mathrm{~s}, 3 \mathrm{H})$, 5.17-5.22 (dd, $J=12.6,7.5 \mathrm{~Hz}, 1 \mathrm{H}), 5.53-5.57(\mathrm{dd}, J=11.6,5.1 \mathrm{~Hz}, 1 \mathrm{H}), 6.41(\mathrm{~s}, 1 \mathrm{H}), 7.41(\mathrm{t}, J=$ $2.7 \mathrm{~Hz}, 1 \mathrm{H}), 7.45(\mathrm{~s}, 1 \mathrm{H}) ;{ }^{13} \mathrm{C} \mathrm{NMR}\left(100 \mathrm{MHz}, \mathrm{CDCl}_{3}\right) 15.2 ; 16.4 ; 16.9 ; 17.0 ; 18.1 ; 19.4 ; 30.9$; $34.4 ; 35.5 ; 38.2 ; 42.1 ; 43.4 ; 51.4 ; 52.0 ; 53.6 ; 64.0 ; 71.2 ; 75.2 ; 108.5 ; 125.5 ; 139.5 ; 143.7 ; 171.1$; 171.6; 172.1; 202.0 ppm; HRESIMS m/z [M+H]+ 490.08 (calcd for $\mathrm{C}_{26} \mathrm{H}_{35} \mathrm{NO}_{8} 489.56$ ).

15. Bikbulatov RV, Yan F, Roth BL, Zjawiony JK. Bioorg.Med.Chem.Lett 2007;17:2229. [PubMed: 17303418]

16. McGovern DL, Mosier PD, Roth BL, Westkaemper RB. J Mol.Graph.Model 2010;28:612. [PubMed: 20083418] 


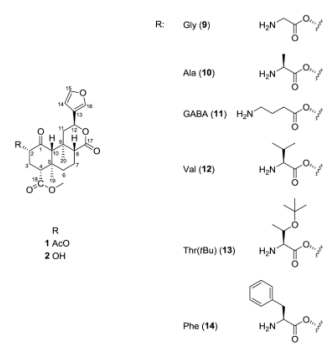

Figure 1.

Structure of salvinorin A (1), salvinorin B (2) and new amino acid analogues. 


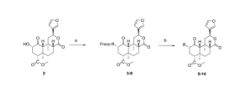

Scheme 1.

Synthesis of amino acid analogues of salvinorin A. Reagents and conditions: a) salvinorin B (2), appropriate $\mathrm{N}$-Fmoc-amino acids, TBTU, $\mathrm{N}$-methylmorpholine, $\mathrm{CH}_{2} \mathrm{Cl}_{2}$, b) deprotection with piperidine in $\mathrm{CH}_{2} \mathrm{Cl}_{2}$. 


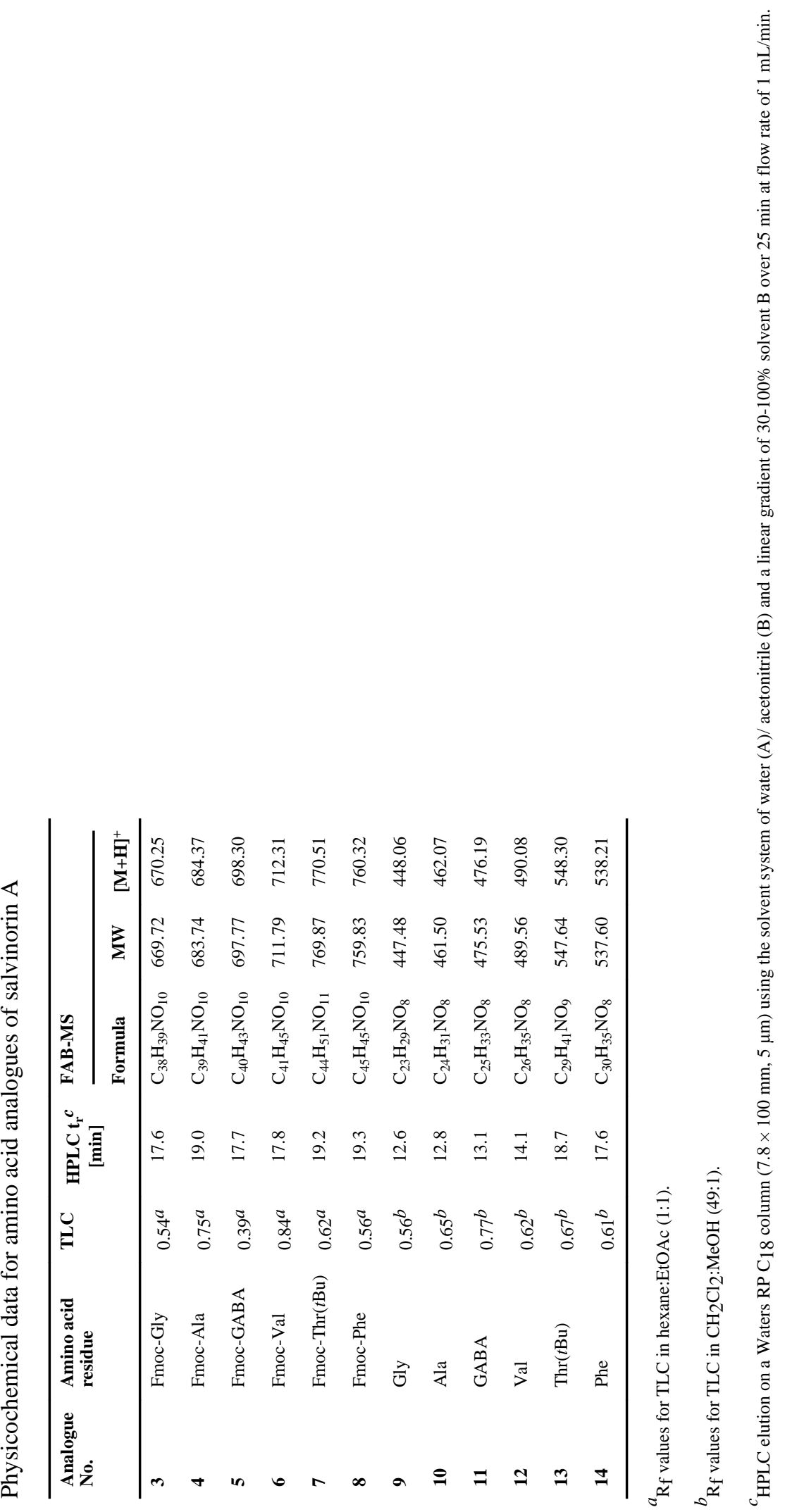




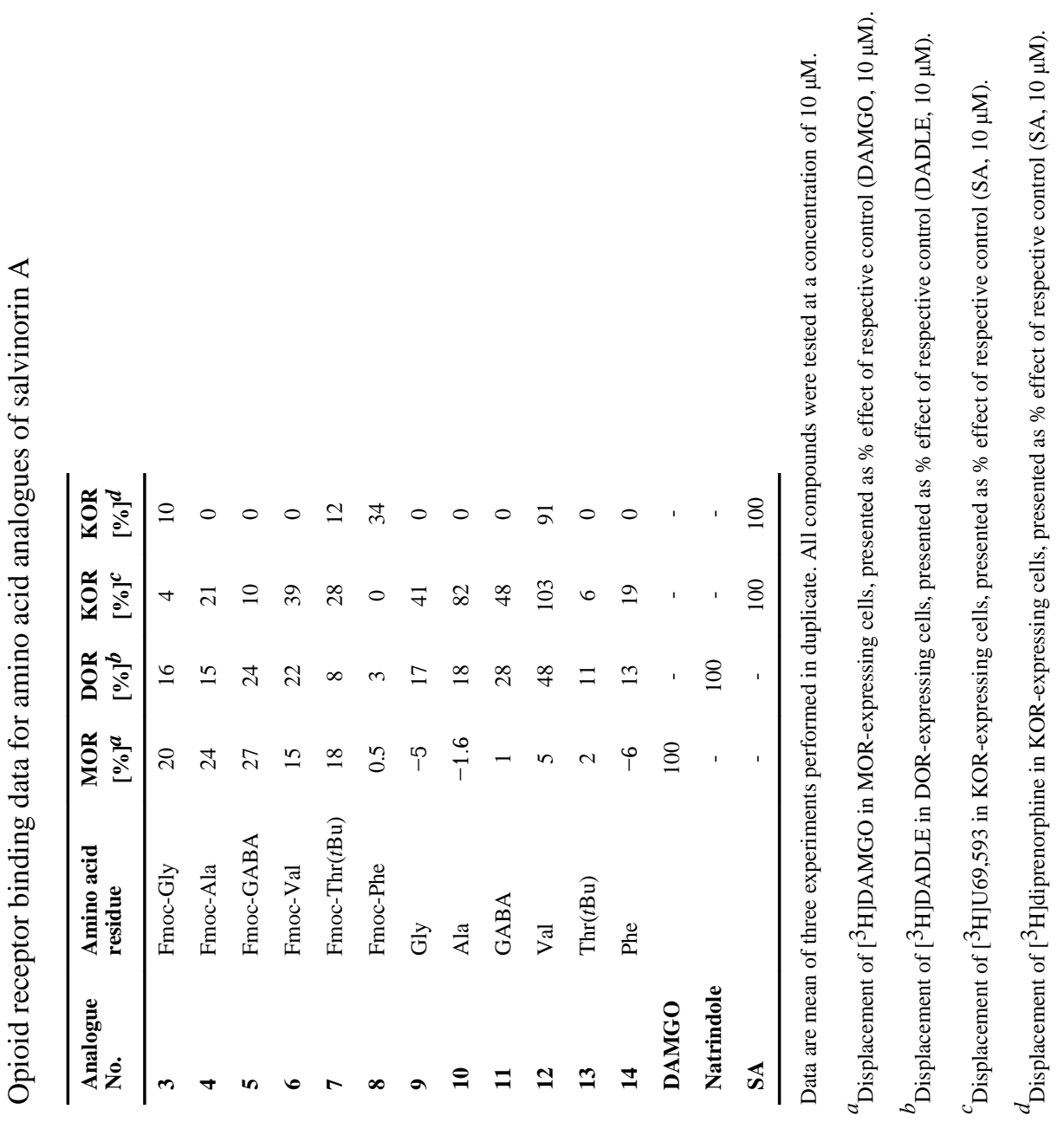




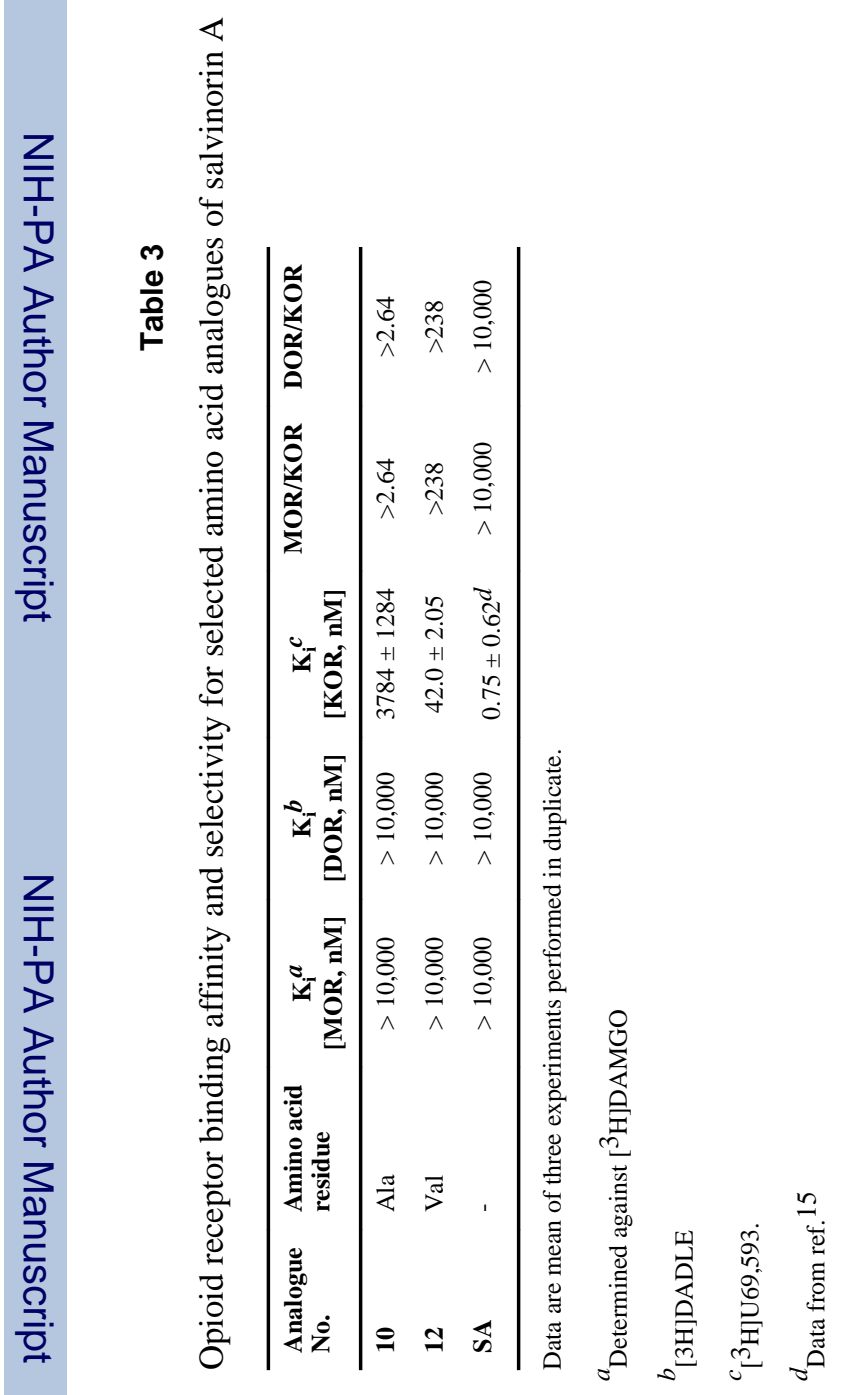




\section{Table 4}

Agonist activity of analogue $\mathbf{1 2}$ in $\left[{ }^{35} \mathrm{~S}\right] \mathrm{GTP} \gamma \mathrm{S}$ binding assay

\begin{tabular}{llccc}
\hline $\begin{array}{l}\text { Analogue } \\
\text { No. }\end{array}$ & $\begin{array}{l}\text { Amino acid } \\
\text { residue }\end{array}$ & $\begin{array}{c}\mathbf{E C}_{\mathbf{5 0}} \\
{[\mathbf{n M}]}\end{array}$ & $\begin{array}{c}\mathbf{E}_{\max } \\
{[\mathbf{\%}]}\end{array}$ & Relative $\mathbf{E}_{\max }$ \\
\hline $\mathbf{1 2}$ & Val & $213 \pm 15.0$ & $828 \pm 275$ & 117.74 \\
$\mathbf{S A}$ & - & $0.2 \pm 0.1$ & $703 \pm 179$ & 100.00 \\
\hline
\end{tabular}

Data are mean \pm SEM of four experiments. 